\title{
ANALISIS SARANA DAN PRASARANA SEKOLAH DASAR BERDASARKAN TINGKAT AKREDITASI DI KOTA TARAKAN
}

\author{
Firima Zona Tanjung ${ }^{1}$, Muhsinah Annisa ${ }^{2}$, Ridwan $^{3}$ \\ ${ }^{1}$ Program Studi Pendidikan Bahasa Inggris, Universitas Borneo Tarakan, Indonesia \\ ${ }^{2,3}$ Program Studi Pendidikan Guru Sekolah Dasar, Universitas Borneo Tarakan, \\ Indonesia
}

E-mail: echa.ok@gmail.com

\begin{abstract}
Abstrak
Tujuan penelitian ini adalah untuk mengidentifikasi sarana dan prasarana pendidikan sekolah dasar di Kota Tarakan berdasarkan tingkat akreditasinya dan menganalisis kesesuaiannya berdasarkan permen 24 tahun 2007. Penelitian ini menggunakan jenis penelitian deskriptif kuantitatif. Pengambilan sampel sekolah berdasarkan akreditasi sekolah, yaitu sekolah akreditasi A, B dan C, yaitu SDN 028 (Akreditasi A), SDN 013 Tarakan (Akreditasi B) dan SDN 021 Tarakan (Akreditasi C). Hasil yang diperoleh yaitu secara keseluruhan sarana prasarana di sekolah dasar layak, kesesuaian sarana prasarana sekolah dasar 80,9\% untuk SDN 028 Tarakan (Akreditasi A), 78,7\% untuk SDN 013 Tarakan (Akreditasi B) dan 55,3\% untuk SDN 021 Tarakan (Akreditasi C) mengacu pada Peraturan Menteri Pendidikan Nasional Republik Indonesia no 24 tahun 2007 tentang Standar Sarana dan Prasarana untuk Sekolah Dasar/Madrasah Ibtidaiyah (SD/MI), Sekolah Menengah Pertama/Madrasah Tsanawiyah (SMP/MTs), dan Sekolah Menengah Atas/Madrasah Aliyah (SMA/MA).
\end{abstract}

Kata Kunci : Sarana Prasarana, Akreditasi, Standar Nasional Pendidikan, Sekolah Dasar

\begin{abstract}
The objectives of this study were to identify the educational structure and infrastructure in Tarakan based on the level of accrediation and to analyze the feasibility of educational structure and infrastructure based on Permendiknas No. 24 of 2007. This study employed a quantitative descriptive research where all primary schools in Tarakan as the population. The purposive sampling technique was used by considering the schools had got accreditation $A$, B, and C. Thus SDN 028 (accrediation A), SDN 013 (accrediation B), and SDN 021 (accrediation C) of Tarakan were taken as the sample. The result of the research showed that the structure and infrastructure of primary schools in Tarakan can be said properly available, where the suitability of structure and infrastructure is respectively $80,9 \%$ for SDN 28 Tarakan (acreditation A), 78,9\% for SDN 013 Tarakan (acreditation B), and 55,3\% for SDN 021 Tarakan ((acreditation C). This result was confirmed with the Regulation of the Minister of National Education and Culture No. 24 of 2007 about the Structure and Infrastructure Standard for Primary Schools/lslamic Primary Schools (SD/MI), Secondary Schools/lslamic Secondary Schools (SMP/MTs), and High Schools/Islamic High Schools (SMA/MA).
\end{abstract}

Key words: Infrastructure, Accreditation, the National Education Standard Elementary School 


\section{PENDAHULUAN}

Tarakan merupakan kota di Kalimantan bagian utara yang berbatasan dengan Negara tetangga, yaitu negara bagian Sabah dan Serawak, Malaysia Timur. Tarakan memiliki pelabuhan ekspor impor dan bandara internasional kelas $C$ yang digunakan sebagai orang sebagai transit dan distribusi barang antar kota dan negara.posisi strategis yang dimiliki Tarakan dapat membuat Tarakan lebih berkembang baik dalam bidang ekonomi, social dan pendidikan.Pendidikan merupakan salah satu faktor dalam mengukur tingkat kemajuan suatu bangsa.

Sebagai kota yang sedang

berkembang, Tarakan telah memprioritaskan pendidikan bagi masyarakatnya. Karena, sebagaian orang memandang bahwa pendidikan dapat membentuk jati diri seseorang, selain itu pendidikan adalah investasi di masa yang akan datang. Investasi ini akan dirasakan masyarakat bukan dalam jangka waktu yang pendek, tetapi akan terasa setelah sepuluh atau dua puluh tahun mendatang. Banyak daerah maju karena masyarakatnya mengenyam pendidikan dengan baik. Karena pendidikan itu identik dengan perkembangan zaman, dan persaingan ilmu pengetahuan. Oleh karena itu pendidikan salah satu faktor dalam menunjang suatu daerah untuk terus bisa berkembang dan maju, sebagaimana yang diamanatkan Pemerintah melalui Departemen Pendidikan Nasional telah berkomitmen untuk meningkatkan standar mutu pendidikan di Indonesia.

Berkaitan dengan sarana dan prasarana pendidikan, Musa (2012) menyebutkan bahwa, "Physical assets for education comprise land, building and furniture and it include physical facilities for teaching spaces and for ancillary rooms" aset fisik untuk pendidikan terdiri dari tanah, bangunan dan furnitur dan mencakup fasilitas fisik untuk ruang pembelajaran dan ruang tambahan. Ibrahim (2004, p.2) menjelaskan bahwa sarana pendidikan adalah semua perangkat peralatan, bahan, dan perabot yang secara langsung dapat digunakan dalam proses pembelajaran/pendidikan sekolah. Senada dengan dua pernyataan di atas, Mulyasa
(2004, p.49) menyatakan bahwa sarana pendidikan adalah peralatan yang secara langsung dipergunakan dan menunjang proses pendidikan atau pengajaran, sedangkan prasarana pendidikan adalah fasilitas yang secara tidak langsung menunjang proses pendidikan atau pengajaran.

Hal senada juga disampaikan oleh Lunenburg (2010) bahwa "School buildings across the nation are aging and becoming a barrier to optimal learning and teaching" yang mengandung pengertian bahwa bangunan atau sarana yang kurang mendukung akan menjadi menghambat dalam proses pembelajaran yang optimal. Kelengkapan sarana dan prasarana akan membantu guru dalam menyelenggarakan proses pembelajaran. Sanjaya (2006) menjelaskan bahwa terdapat beberapa keuntungan bagi sekolah yang memiliki kelengkapan sarana dan prasarana, antara lain: (1) kelengkapan sarana dan prasarana dapat menumbuhkan gairah dan motivasi guru dalam mengajar serta dapat mendorong siswa untuk belajar, sehingga pembelajaran akan menjadi efektif; (2) kelengkapan sarana dan prasarana dapat memberikan kemudahan dalam menentukan berbagai pilihan pada siswa untuk belajar, sehingga proses pembelajaran akan lebih bervariasi. Penelitian yang dilakukan oleh Timilehin (2012, p.208) mengungkapkan bahwa: The study revealed that there was a significant relationship between school facilities and students' achievement in the affective domain as well as a significant relationship between school facilities and students' achievement in the psychomotor domain of learning.

Pelaksanaan pendidikan akan dapat terlaksana lebih baik lagi jika delapan standar nasional pendidikan telah terimplementasikan di satuan pendidikan masing-masing sekolah agar dapat mencapai tujuan pendidikan nasional seperti yang diamanatkan pada peraturan pemerintah nomor 19 tahun 2005 tentang standar nasional pendidikan. Delapan standar tersebut yaitu standar kompetensi lulusan, standar isi, standar proses, standar tenaga pendidik dan kependidikan, standar sarana dan prasarana, standar pengelolaan, 
standar pembiayaan, dan standar penilaian. Delapan standar tersebut saling menunjang satu sama lain dalam mencapai tujuan nasional pendidikan.

Sarana dan prasarana pendidikan merupakan salah satu sumber daya yang penting dalam menunjang proses pembelajaran di sekolah, baik sekolah yang memiliki akreditasi $A, B$, maupun sekolah dasar yang terakreditasi $\mathrm{C}$. Tanpa ditunjang oleh sarana dan prasarana yang memadai sulit diharapkan proses dan hasil pendidikan yang bermutu tinggi. Rendahnya kualitas proses dan hasil pendidikan di Indonesia saat ini, sebagian diduga disebabkan oleh minimnya sarana pendidikan yang disediakan oleh pemerintah maupun yang mampu disediakan oleh masyarakat.

$$
\text { Sejalan dengan kebijakan }
$$

pemerintah yang memberikan kewenangan penuh kepada pihak sekolah/perguruan tinggi selaku industri jasa untuk menyelenggarakan layanan pendidikan secara transparan dan akuntabel. oleh karena itu, seluruh proses pengadaan serta mengoptimalkan pendayagunaan, perawatan dan pengendalian sarana dan prasarana pendidikan pada setiap jenis dan jenjang pendidikan, diperlukan penyesuaian manajemen sarana dan prasarana. Lembaga dituntut memiliki kemandirian untuk mengatur dan mengurus kepentingan rumah tangga (sekolah) menurut kebutuhan dan kemampuan sendiri serta berdasarkan pada aspirasi dan partisipasi warga sekolah dengan tetap mengacu pada peraturan dan perundangundangan pendidikan nasional yang berlaku. Hal tersebut dimaksudkan untuk meningkatkan mutu pendidikan pada semua jenis dan jenjang pendidikan, khususnya pada pendidikan dasar dan menengah. Sebagaimana temuan penelitian (dalam disertasi Joko Santosa, 2011) dijelaskan bahwa, terdapat hubungan yang signifikan antara variabel manajemen sarana prasarana sekolah dengan motivasi berprestasi guru. Dengan kata lain, semakin baik pengelolaan sarana dan prasarana sekolah akan semakin meningkat motivasi berprestasi guru.

Sementara

itu, minimnya ketersediaan sarana pendidikan tidak hanya disebabkan oleh ketidakmampuan masyarakat atau pemerintah, tetapi juga tidak teridentifikasinya jenis sarana pendidikan yang paling esensial dibutuhkan agar suatu proses pendidikan berlangsung secara optimal, untuk menunjang proses pembelajaran yang teratur dan berkelanjutan, setiap satuan pendidikan wajib memiliki sarana dan prasarana yang baik yang meliputi perencanaan pengelolaan, pengadaan, pemanfaatan, pemeliharaan dan juga pengawasan. Hal ini sejalan dengan penelitian Handayani (2016) yang menyatakan bahwa sarana dan prasarana dapat menjadi faktor pendukung terhadap perolehan mutu lulusan di SDN 016 Tarakan. Hal senada juga diungkapkan Bianti (2012) yang menyatakan bahwa sarana prasarana memiliki pengaruh terhadap prestasi belajar belajar siswa.

Berdasarkan latar belakang tersebut, perlu dikaji sarana dan prasarana pendidikan sekolah dasar di Kota Tarakan berdasarkan tingkat akreditasinya dan menganalisis kesesuaiannya berdasarkan permen 24 tahun 2007. Untuk dapat dilakukan perbaikan kebijakan pembangunan khususnya pemenuhan standar nasional pendidikan pada standar sarana dan prasarana guna meningkatkan kualitas pendidikan di kota Tarakan dan dianalisis kesesuannya mengacu pada permen 24 tahun 2007.

\section{METODE}

Penelitian yang dilaksanakan menggunakan jenis penelitian deskriptif kuantitatif. Populasi dalam penelitian ini adalah sekolah dasar di kota Tarakan. Pengambilan sampel sekolah berdasarkan akreditasi sekolah, yaitu sekolah akreditasi A, B dan C, yaitu SDN 028 (Akreditasi A), SDN 013 Tarakan (Akreditasi B) dan SDN 021 Tarakan (Akreditasi C). Jenis data yang digunakan dalam penelitian ini adalah data primer dan data sekunder. Data primer adalah data yang diperoleh langsung oleh peneliti, yaitu data sarana prasarana yang diperoleh melalui observasi menggunakan lembar pengamatan sarana dan prasarana. Data sekunder adalah data sekunder adalah data yang diperoleh peneliti dari sumber yang sudah ada, yaitu dokumentasi, data inventaris sekolah dan wawancara dengan pihak sekolah. Data dikumpulkan dengan 
teknik observasi dan analisis dokumen. Teknik observasi digunakan untuk melihat langsung ketersediaan dan kondisi sarana dan prasarana yang ada disekolah. Sedangkan data invetarisasi sarana dan prasarana diperoleh dengan cara menganalisis dokumen yang ada di sekolah (luas lahan, jumlah siswa, jumlah guru, dll). Data sarana dan prasarana pendidikan selanjutnya dibandingkan dengan standar minimum sarana dan prasaranan yang tertuang dalam Permen nomor 24 Tahun 2007 tentang standar sarana dan prasarana untuk di analisis kelayakannya.

\section{HASIL DAN PEMBAHASAN}

Dalam kegiatan pengelolaan sarana dan prasarana di SDN 028, 013 dan 021 Tarakan terdiri atas 7 unsur. Dalam melakukan pengelolaan sarana prasarana pihak sekolah melakukan perencanaan setelah itu melakukan pengadaan kemudian sarana prasarana di inventarisasi setelah itu sarana dan prasarana dilakukan pemeliharaan dan melakukan pengawasan serta pertanggung jawaban, dan dalam melakukan pengelolaan sarana dan prasarana pihak sekolah memiliki sistem informasi sarana dan prasarana sekolah ini memiliki situs seperti data base. Untuk unsur penghapusan 3 sekolah tersebut belum melakukan penghapusan tetapi sekolah sudah melakukan pendataan selama 5 tahun sekali apabila barang-barang yang diajukan untuk dihapus barang tersebut biasanya dijual atau diperbaiki.

$$
\text { Dalam melakukan pengadaan }
$$
sarana dan prasarana di SDN 028 dan 013 Tarakan menerapkan Prinsip-prinsip berikut meliputi menampung usulan pengadaan dari berbagai sumber (guru, tenaga kependidikan, komite sekolah, stakeholders), menyesuaikan dengan analisis kebutuhan yang sudah dibuat sebelumnya, menyesuaikan antara kebutuhan sarana dan prasarana baru dengan anggaran yang tersedia, menyusun rencana kebutuhan sarana dan prasarana dalam kurun waktu 1 tahun, membuat skala prioritas pengadaan sarana prasarana, penetapan rencana untuk tahun depan membeli barang sesuai dengan kebutuhan yang wajib, tata cara pengadaan yang dilakukan sekolah dapat ditempuh adalah membeli langsung dari toko, pabrik, atau produsen. Namun Prinsip- prinsip pengadaan sarana dan prasarana di SDN 021 Tarakan yaitu masing-masing kelas mengajukan usulan kemudian dibicarakan melalui rapat, usulan yang dibicarakan pada rapat disesuaikan dengan kemampuan dan anggaran sekolah. Saran yang tidak bisa ditanggung oleh anggaran sekolah diajukan kepada Dinas Pendidikan kemudian kolektif masuk ke APBD. Penyusunan rencana dilakukan setiap satu tahun, apa yang diusulkan harus sesuai dengan kebutuhan real di lapangan dan dipertimbangkan kemampuan dananya maka berlaku skala prioritas, ada dua tempat untuk skala prioritas yaitu dalam perencanaan dan aplikasinya. Pengadaan dalam setahun ada empat kali (triwulan I, II, III, dan IV) karena sistem pencairan dana seperti itu. Mayoritas tata cara pengadaan beli langsung dari toko, dari dinas pendidikan yang disuplai untuk setiap sekolah, pengadaan dari orang tua, dan membuat sendiri seperti membuat gudang sendiri oleh pihak sekolah dan perencanaan pembuatan ruang ibadah.

Dalam melakukan pendistribusian sarana dan prasarana SDN 028, 013 dan 021 Tarakan menerapkan Prinsip-prinsip berikut meliputi sarana dan prasarana yang sudah diinventarisasi didistribusikan sesuai dengan penggunaannya langsung didistribusikan dikelas masing-masing, pemanfaatan barang memperhatikan prinsip ada yang efektif dan ada juga yang tidak efektif, jumlah sarana dan prasarana sudah mencukupi kebutuhan di sekolah. Adapun prinsip yang tidak diterapkan pihak sekolah yaitu pemanfaatan atau penggunaan sarana dan prasarana sekolah tidak ada sop, alatalat elektronik dan alat lain yang mahal atau relatif sulit pengoperasiannya jadi dibuatkan cara pemakaian secara jelas.

Ketentuan pemeliharaan sarana dan prasarana yang dilakukan di SDN 028 yaitu sarana dan prasarana dilakukan pemeliharaan secara berkala selama 1 tahun sekali dibagi menjadi 3 bulan sekali dengan melakukan pemeliharaan untuk barang-barang yang rusak dilakukan per triwulan didata dulu kemudian diperbaiki, Sedangkan Ketentuan pemeliharaan sarana dan prasarana yang dilakukan di SD 013 Tarakan yaitu sarana dan prasarana 
dilakukan pemeliharaan secara berkala selama 1 tahun sekali dan SD 013 dan 028 Tarakan tidak memperhatikan kalender sekolah dalam melakukan pemeliharaan, tidak memperhatikan kategoti sifat pemeliharaan seperti pengecekan lahanlahan gedung yang rusak, pencegahan, perbaikan ringan dan perbaikan berat dan melakukan perbaikan sesuai dengan RKS, pemeliharaan sarana dan prasarana elektronik sekolah membeli spare-part untuk komputer, dan penggantian dengan spesifikasi program/alat yang baru agar tidak ketinggalan karena sekolah langsung membeli alat yang baru, tidak memperhatikan kalender sekolah, tidak memperhatikan kategoti sifat pemeliharaan seperti pengecekan, pencegahan, perbaikan ringan dan perbaikan berat.

Pemeliharaan sarana dan prasarana elektronik sekolah tidak pernah membeli spare-part yang baru, dan penggantian dengan spesifikasi program/alat yang baru agar tidak ketinggalan karena sekolah langsung membeli alat yang baru. Namun Sekolah melakukan pemeliharaan sarana prasarana dengan memasukkan ketentuan ke dalam perencanaan setiap tahun atau secara berkala, misalnya dalam hal perbaikan yang mana perbaikan itu sendiri dibagi dua yaitu dalam skala ringan dan skala berat, skala ringan dapat dibiayai oleh dan BOS, kemudian untuk skala berat tidak bisa. Untuk pemeliharaan sarana dan prasarana sudah dimasukkan pada POS anggaran sekolah dan memang harus ada anggaran tersendiri untuk pemeliharaan sarana dan prasarana.

Penghapusan sarana dan prasarana di sekolah SDN 028 Tarakan belum ada penghapusan, sekolah masih melakukan pendataan. Sedangkan penghapusan sarana dan prasarana di sekolah SDN 013 Tarakan belum ada penghapusan dan penghapusan bukan dari pihak sekolah tetapi DP2KA. Begitupun Persyaratan penghapusan sarana dan prasarana di sekolah belum dapat dipenuhi karena di SDN 021 Tarakan belum diadakan penghapusan. Proses penghapusan panjang yaitu dari instansi badan unit atau dari sekolah mendata barang, didata jumlah spesifikasi barangnya, dipotret, dan diusulkan ke dinas pendidikan kemudian ke
DP2K untuk dilakukan peninjauan, setelah peninjauan dan dipertimbangkan kemudian dibuatkan berita acara untuk penghapusan barang.

Untuk rasio minimum luas lahan di SDN 028 Tarakan terhadap siswa yaitu 10 $\mathrm{m}^{2} /$ peserta didik rasio tersebut sudah sesuai dengan SNP berdasarkan permen no 24 tahun 2007 jika banyak rombel 19-24 dengan bangunan 3 lantai rasio minimumnya adalah $4,1 \mathrm{~m}^{2} /$ peserta didik, maka dapat disimpulkan bahwa rasio minimum luas lahan di SDN 028 Tarakan terhadap siswa yaitu $10 \mathrm{~m}^{2} /$ peserta didik sudah melebihi dari ketentuan di permen yaitu minimum rasionya adalah 4,1 $\mathrm{m}^{2} /$ peserta didik jadi sesuai dengan SNP. Sedangkan untuk rasio minimum luas lahan di SDN 013 Tarakan terhadap siswa yaitu 6 $\mathrm{m}^{2} /$ peserta didik rasio tersebut sudah sesuai dengan SNP berdasarkan permen no 24 tahun 2007 jika banyak rombel 13-18 dengan bangunan 2 lantai rasio minimumnya adalah $5,6 \mathrm{~m}^{2} /$ peserta didik, maka dapat disimpulkan bahwa rasio minimum luas lahan di SDN 013 Tarakan terhadap siswa yaitu $6 \mathrm{~m}^{2} /$ peserta didik sudah melebihi dari ketentuan di permen yaitu minimum rasionya adalah 5,6 $\mathrm{m}^{2} /$ peserta didik jadi sesuai dengan SNP. Lahan sekolah memenuhi ketentuan rasio minimum luas lahan terhadap peserta didik yaitu $6,5 \mathrm{~m}^{2} / \mathrm{siswa}$ dan menurut Kepala SDN 021 Tarakan lahan sekolah sangat memadai dan merupakan salah satu sekolah di Tarakan yang terluas lahannya, halamannya luas dan cukup bagus.

Untuk luas minimum lahan untuk SDN 028 Tarakan yaitu $3640 \mathrm{~m}^{2}$ rasio tersebut sudah sesuai dengan SNP berdasarkan permen no 24 tahun 2007 jika banyak rombel 19-24 dengan bangunan 3 lantai rasio minimumnya adalah 1460 $\mathrm{m}^{2} /$ peserta didik, maka dapat disimpulkan bahwa rasio minimum lahan terhadap siswa di SDN 028 Tarakan yaitu $3640 \mathrm{~m}^{2} /$ peserta didik sudah melebihi dari ketentuan di permen yaitu minimum rasionya adalah $1460 \mathrm{~m}^{2} /$ peserta didik jadi sesuai dengan SNP. Sedangkan Untuk luas minimum lahan untuk SDN 013 Tarakan yaitu $2993 \mathrm{~m}^{2}$ rasio tersebut sudah sesuai dengan SNP berdasarkan permen no 24 tahun 2007 jika banyak rombel 13-18 dengan bangunan 2 
lantai rasio minimumnya adalah 1690 $\mathrm{m}^{2} /$ peserta didik, maka dapat disimpulkan bahwa rasio minimum lahan terhadap siswa di SDN 013 Tarakan yaitu $2993 \mathrm{~m}^{2} /$ peserta didik sudah melebihi dari ketentuan di permen yaitu minimum rasionya adalah $1690 \mathrm{~m}^{2} /$ peserta didik jadi sesuai dengan SNP. Begitupun di SDN 021 Tarakan sudah sesuai SNP , Lahan sangat memadai luas minimal yaitu $2038,4 \mathrm{~m}^{2}$ dan merupakan salah satu sekolah di Tarakan yang terluas lahannya, halaman yang luas dan cukup bagus.

SDN 028, 013, dan 021 Tarakan tidak menyewa sekolah namun SD tersebut milik pemkot. Lahan sekolah SDN 028, 013, dan 021 Tarakan memenuhi persyaratan yaitu berada di lokasi yang aman, memenuhi kemudahan akses, terhindar dari potensi bahaya yang mengancam kesehatan fisik, terhindar dari potensi bahaya keselamatan jiwa, berada di lokasi yang terhindar dari gangguan pencemaran air, berada di lokasi yang terhindar dari gangguan pencemaran udara, berada di lokasi yang terhindar dari gangguan pencemaran tanah, berada, memiliki akses untuk penyelamatan dalam keadaan darurat. semua memenuhi persyaratan kecuali di SDN 028 terdapat kebisingan namun dapat teratasi dengan melakukan komunikasi dengan melakukan kerjasama dengan pihak bengkel las. Begitupun di SDN 021 Tarakan, terdapat pencemaran tanah oleh kotoran berupa sisa minyak pengeboran serta memiliki akses untuk penyelamatan dalam keadaan darurat.

SDN 013 Tarakan berada dilokasi peruntukan yang sesuai dengan peruntukan, memiliki status hak atas tanah, memiliki ijin pemanfaatan dari pemegang hak atas tanah dan memilki ijin mendirikan bangunan. Begitupun di SDN 021 Tarakan berada di lokasi yang sesuai dengan peruntukan, memiliki status hak atas tanah, memiliki ijin pemanfaatan dari pemegang hak atas tanah, serta memiliki ijin mendirikan bangunan. Sedangkan SDN 028 Tarakan berada dilokasi peruntukan yang sesuai dengan peruntukan, belum memiliki status hak atas tanah, belum memiliki ijin pemanfaatan dari pemegang hak atas tanah dan belum memilki ijin mendirikan bangunan semuanya masih dalam tahap proses.

Untuk rasio minimum luas lantai di SDN 028 Tarakan terhadap siswa yaitu 9,2 $\mathrm{m}^{2}$ /peserta didik rasio tersebut sudah sesuai dengan SNP berdasarkan permen no 24 tahun 2007 jika banyak rombel 19-24 dengan bangunan 3 lantai rasio minimumnya adalah $3,3 \mathrm{~m}^{2} /$ peserta didik, maka dapat disimpulkan bahwa rasio minimum luas lantai di SDN 028 Tarakan terhadap siswa yaitu $9,2 \mathrm{~m}^{2} /$ peserta didik sudah melebihi dari ketentuan di permen yaitu minimum rasionya adalah $3,3 \mathrm{~m}^{2} /$ peserta didik jadi sesuai dengan SNP. Sedangkan untuk rasio minimum luas lantai di SDN 013 Tarakan terhadap siswa yaitu 4 $\mathrm{m}^{2} /$ peserta didik rasio tersebut sudah sesuai dengan SNP berdasarkan permen no 24 tahun 2007 jika banyak rombel 13-18 dengan bangunan 2 lantai rasio minimumnya adalah $3,4 \mathrm{~m}^{2} /$ peserta didik, maka dapat disimpulkan bahwa rasio minimum luas lantai di SDN 013 Tarakan terhadap siswa yaitu $4 \mathrm{~m}^{2} /$ peserta didik sudah melebihi dari ketentuan di permen yaitu minimum rasionya adalah 3,4 $\mathrm{m}^{2}$ /peserta didik jadi sesuai dengan SNP. Begitupun SDN 021 Tarakan memiliki Lantai sekolah juga memenuhi ketentuan luas minimal sesuai dengan rasio jumlah siswa yaitu $3,1 \mathrm{~m}^{2} /$ siswa dan luas minimun lantai bangunan yaitu $1128,4 \mathrm{~m}^{2}$. Menurut Kepala SDN 021 Tarakan lantai sekolah memenuhi ketentuan luas minimal sesuai dengan rasio jumlah siswa dan lantai gedung.

Untuk luas minimum lantai bangunan untuk SDN 028 Tarakan yaitu $5152 \mathrm{~m}^{2}$ rasio tersebut sudah sesuai dengan SNP berdasarkan permen no 24 tahun 2007 jika banyak rombel 19-24 dengan bangunan 2 lantai rasio minimumnya adalah 1310 $\mathrm{m}^{2} /$ peserta didik , maka dapat disimpulkan bahwa rasio minimum lantai bangunan terhadap siswa di SDN 028 Tarakan yaitu $5152 \mathrm{~m}^{2} /$ peserta didik sudah melebihi dari ketentuan di permen yaitu minimum rasionya adalah $1310 \mathrm{~m}^{2} /$ peserta didik jadi sesuai dengan SNP. Untuk luas minimum lantai bangunan untuk SDN 013 Tarakan yaitu $1784 \mathrm{~m}^{2}$ rasio tersebut sudah sesuai dengan SNP berdasarkan permen no 24 tahun 2007 jika banyak rombel 13-18 dengan bangunan 2 lantai rasio 
minimumnya adalah $1010 \mathrm{~m}^{2} /$ peserta didik , maka dapat disimpulkan bahwa rasio minimum lantai bangunan terhadap siswa di SDN 013 Tarakan yaitu $1784 \mathrm{~m}^{2} /$ peserta didik sudah melebihi dari ketentuan di permen yaitu minimum rasionya adalah $1010 \mathrm{~m}^{2} /$ peserta didik jadi sesuai dengan SNP. Begitupun luas minimun lantai bangunan SDN 021 Tarakan yaitu 1128,4 $\mathrm{m}^{2}$. Menurut Kepala SDN 021 Tarakan lantai sekolah memenuhi ketentuan luas minimal sesuai dengan rasio jumlah siswa dan lantai gedung.

Bangunan sekolah di SDN 028, 013 dan 021 Tarakan memiliki ketentuan struktur yang stabil, kokoh, ada penangkal petir belum dilengkapi dengan sistem pencegahan bahaya kebakaran. begitupun Sanitasi sekolah SDN 028, 013,021 Tarakan memenuhi persyaratan kesehatan yaitu memiliki sanitasi di dalam dan di luar bangunan untuk memenuhi kebutuhan air bersih, memiliki saluran air kotor, memiliki tempat sampah dengan jumlah yang cukup, dan memiliki saluran air hujan selain itu di SDN 028 terdapat air limbah air wudhu di alirkan dikolam ikan lele.

Di SDN 028 Tarakan Bangunan sekolah memiliki ventilasi udara dan ventilasi pencahayaan yang memadai. Memiliki instalasi listrik dengan daya lebih dari 900 watt yaitu 9000 watt. Sekolah memiliki 15 sarana dan prasarana yang lengkap. Di SDN 013 Tarakan Bangunan sekolah memiliki ventilasi udara dan ventilasi pencahayaan yang memadai. Memiliki instalasi listrik dengan daya lebih dari 900 watt yaitu 5625 watt. Sarana dan prasarana sudah sesuai dengan ketentuan yaitu memiliki sebanyak 14 sarana dan prasarana, yang belum tersedia yaitu tempat cuci tangan di setiap depan kelas dengan air yang mengalir, ada beberapa sarana dan prasarana yang tidak dimiliki SDN 013 Tarakan yaitu ruang laboratorium dan dan tempat cuci tangan di setiap depan kelas dengan air yang mengalir hanya beberapa tempat cuci tangan yang tersedia. Sedangkan di SDN 021 Tarakan Bangunan sekolah juga dilengkapi ventilasi udara dan ventilasi pencahayaan yang sangat memadai. Bangunan sekolah memiliki instalasi listrik yang mempunyai daya 3500 watt. Namun, Sekolah SDN 021 Tarakan memiliki sarana dan prasarana sesuai dengan ketentuan meliputi halaman sekolah, ruang kelas, ruang guru / kepala sekolah, perpustakaan, tempat olahraga, uks, gudang, kamar mandi/wc/jamban, kebun sekolah, pagar sekolah, tempat sampah dan kelengkapannya. Namun sekolah belum mempunyai ruang laboratorium, tempat ibadah, tempat ibadah, dan tempat cuci tangan di setiap depan kelas dengan air yang mengalir. Untuk ruangan yang belum ada di sekolah, telah diupayakan agar ruangan tersebut dibuat di sekolah namun masih dimasukkan di dalam perencanaan sekolah.

SDN 028 Tarakan memiliki ruang kelas yaitu satu ruang kelas digunakan untuk beberapa rombel dengan sistem paralel. ukuran ruang kelas minimal $56 \mathrm{~m}^{2}(7$ $\mathrm{m} \times 8 \mathrm{~m}$ ). jumlah siswa per kelas rata-rata 30 peserta didik, perabot/meubelair lengkap dan dalam kondisi baik namun rak penyimpanan hasil karya siswa hanya beberapa kelas saja. ventilasi dan pencahayaan ruang memadai. kondisi ruang bersih, rapi dan terawa/terpelihara dengan baik. tidak memiliki kartu inventaris didalam ruangan. SDN 013 Tarakan memiliki ruang kelas sesuai dengan ketentuan yaitu satu ruang kelas satu rombel. ukuran ruang kelas minimal $56 \mathrm{~m}^{2}(7 \mathrm{~m} \times 8 \mathrm{~m})$. jumlah siswa per kelas 30 peserta didik, perabot/meubelair lengkap dan dalam kondisi baik namun ada beberapa kelas yang tidak memiliki lemari ,papan pajang serta rak penyimpanan hasil karya siswa dan juga pencuci tangan hanya sebagian saja ditempat-tempat tertentu. ventilasi dan pencahayaan ruang memadai. kondisi ruang bersih, rapi dan terawa/terpelihara dengan baik. memiliki kartu inventaris ruangan. Di SDN 021 Tarakan Ruang kelas yang dimiliki sekolah belum memenuhi ketentuan karena masih ada 2 rombel kelas yang bergantian yaitu kelas II dengan kelas I. Masih kekurangan siswa dan ada mutasi dua orang, serta mengadakan anggaran untuk meja dan kursi untuk siswa mutasi. Sekolah belum memiliki perabot lengkap namun dalam kondisi baik, ventilasi dan pencahayaan ruang memadai serta kondisi ruang bersih, rapi, terawat dengan baik. Untuk kartu inventaris ruangan sebelumnya ada, namun tercecer oleh guru. 
Sekolah memiliki ruang guru sesuai dengan ketentuan yaitu ukuran ruang minimal $56 \mathrm{~m}^{2}$ di sdn 028 Tarakan. perabot/meubelair lengkap dan dalam kondisi baik. ventilasi dan pencahayaan ruang memadai. kondisi ruang bersih, rapi dan terawa/terpelihara dengan baik. tidak memiliki kartu inventaris ruangan. SDN 013 Tarakan memiliki ruang guru sesuai dengan ketentuan yaitu ukuran ruang minimal $56 \mathrm{~m}^{2}$ di sdn 013 Tarakan ruang guru memiliki ukuran $78 \mathrm{~m}^{2}$ sehingga memenuhi ketentuan. perabot/meubelair lengkap dan dalam kondisi baik. ventilasi dan pencahayaan ruang memadai. kondisi ruang bersih, rapi dan terawa/terpelihara dengan baik. memiliki kartu inventaris ruangan. Sedangkan SDN 021 Tarakan memiliki ruang guru yang memenuhi ukuran ketentuan yang ada, namun perabot belum lengkap, ventilasi dan pencahayaan ruang memadai, kondisi ruang bersih, rapi, dan terwat dengan baik, namun belum memiliki kartu inventaris ruangan.

SDN 028 Tarakan memiliki ruang kepala sekolah sesuai dengan ketentuan ukuran ruang minimal $21 \mathrm{~m}^{2}$ namun ruang kepala sekolah kurang dari $21 \mathrm{~m}^{2}$ sehingga belum memnuhi ketentuan. perabot/meubelair lengkap dan dalam kondisi baik. ventilasi dan pencahayaan ruang memadai. kondisi ruang kepala sekolah terawat/terpelihara dengan baik. tidak memiliki kartu inventaris ruangan. Sedangkan SDN 013 Tarakan memiliki ruang kepala sekolah sesuai dengan ketentuan ukuran ruang minimal $21 \mathrm{~m}^{2}$ namun ruang kepala sekolah hanya $20 \mathrm{~m}^{2}$ sehingga belum memenuhi ketentuan, perabot/meubelair lengkap dan dalam kondisi baik. Ventilasi tidak ada karena menggunakan $\mathrm{AC}$ dan pencahayaan ruang memadai. kondisi ruang kepala sekolah terawat/terpelihara dengan baik. memiliki kartu inventaris ruangan. SDN 021 Tarakan juga memiliki ruang kepala sekolah yang ukurannya sesuai dengan ketentuan, namun perabot belum lengkap karena belum ada brankas, ventilasi dan pencahayaan ruang memadai kondisi ruang kepala sekolah terawat/terpelihara dengan baik, namun belum memiliki kartu inventaris ruangan.

SDN 028 Tarakan memiliki ruang perpustakaan sesuai dengan persyaratan yaitu ruang perpustakaan berfungsi sebagai tempat kegiatan siswa dan guru memperoleh informasi dari berbagai jenis bahan pustaka dengan membaca, mengamati, dan/atau mendengar, luas minimum ruang perpustakaan sama dengan luas satu ruang kelas yaitu minimal $56 \mathrm{~m}^{2}(7$ $\mathrm{m} \times 8 \mathrm{~m}$ ), lebar minimum ruang perpustakaan adalah $5 \mathrm{~m}$, ruang perpustakaan dilengkapi jendela untuk memberi pencahayaan yang memadai untuk membaca buku, ruang perpustakaan terletak di bagian sekolah yang mudah dicapai. Ruang perpustakaan sekolah dilengkapi sarana berikut yaitu buku teks pelajaran, buku panduan pendidik, buku pengayaan, buku referensi, sumber belajar lain , perabot: rak buku, memiliki perabot: rak majalah rak surat kabar, perabot: meja baca, kursi kerja, meja kerja/sirkulasi, perabot, lemari, dan meja multimedia, perlengkapan: buku inventaris, buku peminjaman, buku kunjungan, buku lainnya, perlengkapan: tempat sampah, kotak kontak, jam dinding, tidak memiliki media pendidikan: peralatan multimedia (TV, VCD, tape recorder, radio, dII).

Persyaratan

pemanfaatan perpustakaan sebagai sumber belajar untuk SDN 028 Tarakan sudah memenuhi persyaratan seperti ada jadwal pemanfaatan, dimanfaatkan oleh kepala sekolah, dimanfaatkan oleh guru, dimanfaatkan oleh siswa, dimanfaatkan oleh tenaga kependidikan. Di SDN 013 Tarakan sekolah memiliki ruang perpustakaan sesuai dengan persyaratan yaitu ruang perpustakaan berfungsi sebagai tempat kegiatan siswa dan guru memperoleh informasi dari berbagai jenis bahan pustaka dengan membaca, mengamati, dan/atau mendengar, luas minimum ruang perpustakaan sama dengan luas satu ruang kelas yaitu minimal $56 \mathrm{~m}^{2}(7 \mathrm{~m} \times 8 \mathrm{~m})$, lebar minimum ruang perpustakaan adalah $5 \mathrm{~m}$, ruang perpustakaan dilengkapi jendela untuk memberi pencahayaan yang memadai untuk membaca buku, ruang perpustakaan terletak di bagian sekolah yang mudah dicapai. Ruang perpustakaan sekolah dilengkapi sarana berikut yaitu buku teks pelajaran, buku panduan pendidik, buku pengayaan, buku referensi, sumber belajar lain , perabot: rak buku, perabot: meja baca, 
kursi kerja, meja kerja/sirkulasi, perabot:, lemari, dan meja multimedia, perlengkapan: buku inventaris, buku peminjaman, buku kunjungan, buku lainnya, perlengkapan: tempat sampah, kotak kontak, jam dinding namun tidak memiliki perabot: rak majalah rak surat kabar, tidak memiliki media pendidikan: peralatan multimedia (TV, VCD, tape recorder, radio, dll). Persyaratan pemanfaatan perpustakaan sebagai sumber belajar untuk SDN 013 Tarakan sudah memenuhi persyaratan seperti ada jadwal pemanfaatan, dimanfaatkan oleh kepala sekolah, dimanfaatkan oleh guru, dimanfaatkan oleh siswa, dimanfaatkan oleh tenaga kependidikan. Sedangkan di SDN 021 Tarakan Sekolah memiliki ruang perpustakaan dan telah memenuhi persyaratan sebagai berikut ruang perpustakaan berfungsi sebagai tempat kegiatan siswa dan guru memperoleh informasi dari berbagai jenis bahan pustaka dengan membaca, mengamati, dan/atau mendengar, luas minimum ruang perpustakaan sama dengan luas satu ruang kelas yaitu minimal $56 \mathrm{~m}^{2}(7 \mathrm{~m} \times 8 \mathrm{~m})$, lebar minimum ruang perpustakaan adalah $5 \mathrm{~m}$. ruang perpustakaan dilengkapi jendela untuk memberi pencahayaan yang memadai untuk membaca buku dan ruang perpustakaan terletak di bagian sekolah yang mudah dicapai.

Persyaratan ruang UKS di SDN 028 Tarakan meliputi: tersedia tempat tidur , tersedia alat-alat kesehatan , tersedia kotak obat-obatan dan isinya, tersedia tempat cuci tangan/wastafel, tersedia poster/pamflet/leaflet info tentang kesehatan, ada program kerja UKS, ada tim pelaksana UKS, ada kartu inventaris ruangan manual, buku catatan hasil kegiatan UKS, buku rujukan berobat ke puskesmas, kondisi ruang uks bersih dan terawat baik. Sedangkan Persyaratan ruang UKS di SDN 013 Tarakan meliputi: tersedia tempat tidur, tersedia alat-alat kesehatan , tersedia kotak obat-obatan dan isinya, tersedia tempat cuci tangan/wastafel, tersedia poster/pamflet/leaflet/info tentang kesehatan, ada program kerja UKS, ada tim pelaksana UKS, ada kartu inventaris ruangan, buku catatan hasil kegiatan UKS, buku rujukan berobat ke puskesmas, kondisi ruang uks bersih dan terawat baik. Di SDN
021 Tarakan ruang perpustakaan dilengkapi 6 macam persyaratan yaitu buku teks pelajaran, perabot: rak buku, perabot: meja baca, kursi baca, kursi kerja, meja kerja/sirkulasi, lemari, untuk empat persyaratan lainnya belum terpenuhi yaitu buku panduan pendidik, buku pengayaan, buku referensi, sumber belajar lain, rak majalah dan rak surat kabar, lemari katalog, papan pengumuman, meja multimedia, dan peralatan multimedia. Persyaratan pemanfaatan perpustakaan sebagai sumber belajar di sekolah memenuhi persyaratan sebagai berikut yaitu ada jadwal pemanfaatan, dimanfaatkan oleh kepala sekolah, dimanfaatkan oleh guru, dimanfaatkan oleh siswa, dan dimanfaatkan oleh tenaga kependidikan.

028 Persyaratan ruang ibadah di SDN perlengkapan ibadah, memiliki tempat berwudlu, memiliki ventilasi dan penerangan , tidak memiliki kartu inventaris ruangan, kondisi ruang ibadah besih, rapi, dan terawat. Sekolah memiliki tempat ibadah yang dimanfaatkan dan memenuhi persyaratan sebagai berikut yaitu digunakan untuk pelaksanaan ibadah. jika dimanfaatkan untuk perayaan hari besar keagamaan tidak mungkin karena jumlah masyarakat sekolah lebih banyak sehingga tidak bisa digunakan untuk acara hari besar. dimanfaatkan oleh warga sekolah dan atau masyarakat. pemanfaatan ruang optimal karena ukurannya memadai digunakan oleh penggunanya. Sedangkan Persyaratan ruang ibadah di SDN 013 Tarakan meliputi:memiliki perlengkapan ibadah, memiliki tempat berwudlu, memiliki ventilasi dan penerangan, memiliki kartu inventaris ruangan, kondisi ruang ibadah besih, rapi, dan terawat. Sekolah memiliki tempat ibadah yang dimanfaatkan dan memenuhi persyaratan sebagai berikut yaitu digunakan untuk pelaksanaan ibadah. jika dimanfaatkan untuk perayaan hari besar keagamaan tidak mungkin karena jumlah masyarakat sekolah lebih banyak sehingga tidak bisa digunakan untuk acara hari besar. dimanfaatkan oleh warga sekolah dan atau masyarakat. pemanfaatan ruang optimal karena ukurannya memadai digunakan oleh penggunanya. Begitupun di SDN 021 Tarakan Usaha Kesehatan Sekolah (UKS) di 
sekolah ini meliputi tersedianya tempat tidur, tersedia alat-alat kesehatan, tersedia kotak obat-obatan dan isinya, tersedia poster/pamflet/leaflet/info, ada program kerja UKS, ada tim pelaksana UKStentang kesehatan, buku catatan hasil kegiatan UKS, buku rujukan berobat ke puskesmas, kondisi ruang uks bersih dan terawat baik. Yang belum terpenuhi yaitu adanya kartu inventaris ruangan dan belum ada wastafel.

Toilet di SDN 028 Tarakan memenuhi persyaratan yaitu :ketersediaan air bersih, tolilet bersih, dan tidak berbau, rasio minimal 1 toilet: 32 siswa, tersedia toilet siswa terpisah antara laki-laki dan perempuan, tersedia toilet guru terpisah antara laki-laki dan perempuan, tersedia kelengkapan toilet (gayung, sabun, tempat sampah). Sedangkan toilet di SDN 013 Tarakan memenuhi persyaratan yaitu: ketersediaan air bersih, tolilet bersih, dan tidak berbau namun ada beberapa toilet yang berbau , rasio minimal 1 toilet: 32 siswa, tersedia toilet siswa terpisah antara laki-laki dan perempuan, tersedia toilet guru terpisah antara laki-laki dan perempuan, tersedia kelengkapan toilet (gayung, sabun, tempat sampah). Begitupun SDN 021 memiliki toilet yang memenuhi persyaratan sebagi berikut ketersediaan air bersih, tolilet bersih, dan tidak berbau, rasio minimal 1 toilet: 32 siswa, tersedia toilet siswa terpisah antara laki-laki dan perempuan, tersedia toilet guru terpisah antara laki-laki dan perempuan. Namun yang belum terpenuhi yaitu kelengkapan toilet seperti tissu, gayung, sabun, cermin, penampung air.

Halaman sekolah di SDN 028 Tarakan telah memenuhi persyaratan meliputi: kondisi bersih dan terawat, ada tanaman pelindung, ada taman sekolah, ada tempat sampah organik dan anorganik, ada tempat cuci tangan dengan air mengalir, luas halaman memadai untuk digunakan semua siswa. Sekolah memiliki halaman dan dimanfaatkan untuk kegiatan: pelaksanaan upacara, latihan olahraga, sarana bermain siswa dan kegiatan ekstrakurikuler. Begitupun halaman sekolah di SDN 013 Tarakan telah memenuhi persyaratan meliputi: kondisi bersih dan terawat, ada tanaman pelindung, ada taman sekolah, ada tempat sampah organik dan anorganik , ada tempat cuci tangan dengan air mengalir, luas halaman memadai untuk digunakan semua siswa. Sekolah memiliki halaman dan dimanfaatkan untuk kegiatan: pelaksanaan upacara, latihan olahraga, sarana bermain siswa dan kegiatan ekstrakurikuler. Sedangkan di SDN 021 memiliki halaman yang kondisinya bersih dan terawat, ada tanaman pelindung, ada taman sekolah, ada tempat cuci tangan dengan air mengalir, luas halaman memadai untuk digunakan semua siswa. Namun belum memiliki tempat sampah organik dan anorganik.Sekolah memiliki halaman dan dimanfaatkan untuk kegiatan pelaksanaan upacara, latihan olahraga, sarana bermain siswa, dan kegiatan ekstrakurikuler.

SDN 028 Tarakan memiliki ruang laboratorium IImu Pengetahuan Alam (IPA) memenuhi persyaratan yaitu laboratorium IPA dapat memanfaatkan ruang kelas, sarana laboratorium ipa berfungsi sebagai alat bantu yang mendukung kegiatan dalam bentuk percobaan, didalam lab IPA ada almari, model kerangka manusia dan atau model tubuh manusia lalu ada globe, ada model tata surya, kaca pembesar, cermin datar, cermin cembung, dan cermin cekung, ada lensa datar, cembung, dan lensa cekung, magnet batang, dan tidak ada poster. Sedangkan SDN 013 dan 021 Tarakan belum memiliki ruang laboratorium Ilmu Pengetahuan Alam (IPA) tetapi untuk SDN 013 Tarakan memiliki beberapa sarana IPA seperti KIT dan torso yang disimpan diruang keterampilan.

Di SDN 028, 013 dan 021 Tarakan mengadakan alat peraga/praktik untuk pembelajaran dengan ketentuan: sebagian besar dibuat oleh siswa/guru, alat yang dibuat berasal dari bahan yang mudah diperoleh, dan murah harganya, alat peraga yang dibeli sesuai dengan kebutuhan.

SDN 028 Tarakan memanfaatkan kebun sekolah sebagai sumber belajar, kebun sekolah ditanami berbagai macam tanaman apotek hidup, kebun sekolah ditanami berbagai macam tanaman holikultura (sayur mayur), kebun sekolah digunakan sebagai sarana praktik dalam kebun sekolah bersih dan terawat. Begitupun SDN 021 Tarakan memanfaatkan kebun sekolah sebagai sumber belajar, kebun sekolah ditanami berbagai macam tanaman apotik hidup, kebun sekolah 
ditanami berbagai macam tanaman holtikultura (sayur mayur), kebun sekolah digunakan sebagai sarana paktik dalam kebun sekolah bersih dan terawat. Namun pemanfaatan kebun sekolah sebagai sumber belajar belum maksimal diterapkan. Sedangkan SDN 013 Tarakan belum memanfaatkan kebun sekolah, sebagai sumber belajar, kebun sekolah belum ditanami berbagai macam tanaman apotik hidup, kebun sekolah belum ditanami berbagai macam tanaman holtikultura (sayur mayur) tetapi sdn 013 memiliki kebun hidroponik yang ditanami sayur sawi.

Gudang di SDN 028 dan 013 Tarakan memenuhi persyaratan seperti gudang berfungsi sebagai tempat menyimpan peralatan pembelajaran di luar kelas, gudang berfungsi sebagai tempat menyimpan sementara peralatan sekolah yang tidak/belum berfungsi, gudang tidak berfungsi sebagai tempat menyimpan arsip sekolah yang telah berusia lebih dari 5 tahun, melainkan gudang digunakan sebagai ruang penyimpanan alat olahraga. Luas gudang di sdn 028 tarakan adalah 12 $\mathrm{m}^{2}$, sedangkan luas gudang di sdn 013 tarakan adalah $21 \mathrm{~m}^{2}$, gudang dapat dikunci, ada almari yang memadai untuk menyimpan alat-alat dan arsip berharga , almari dalam kondisi baik, kuat, stabil, dan aman, ada rak yang memadai untuk menyimpan peralatan olahraga, rak dalam kondisi baik, kuat, stabil, dan aman. Begitupun Gudang di SDN 021 Tarakan memenuhi persyaratan sebagai berikut yaitu gudang berfungsi sebagai tempat menyimpan peralatan pembelajaran di luar kelas, gudang berfungsi sebagai tempat menyimpan sementara peralatan sekolah yang tidak/belum berfungsi, gudang berfungsi sebagai tempat menyimpan arsip sekolah yang telah berusia lebih dari 5 tahun, luas gudang minimum $18 \mathrm{~m}^{2}$, gudang dapat dikunci, almari dalam kondisi baik, kuat, stabil, dan aman, namun rak yang memadai untuk menyimpan peralatan olahraga, kesenian, dan keterampilan, sertaada kartu inventaris ruangan namun belum ada almari yang memadai.

Ruang sirkulasi di SDN 028, 013 dan

021 Tarakan meliputi ruang sirkulasi horizontal berfungsi sebagai tempat penghubung antar ruang dalam bangunan sekolah, ruang sirkulasi horizontal beratap, dan mendapat pencahayaan serta penghawaan yang cukup, ruang sirkulasi horizontal berfungsi sebagai tempat berlangsungnya kegiatan bermain dan interaksi sosial siswa di luar jam pelajaran, ruang sirkulasi horizontal berfungsi sebagai tempat berlindung pada saat hujan ketika tidak memungkinkan kegiatan-kegiatan tersebut berlangsung di dalam kelas atau di halaman sekolah., ruang sirkulasi horizontal luas minimum adalah $30 \%$ dari luas total seluruh ruang pada bangunan, lebar minimum adalah 3-4 $\mathrm{m}$, dan tinggi minimum $2,5 \mathrm{~m}$.

Tempat bermain/berolahraga di sekolah memenuhi persyaratan yaitu: tempat bermain/berolahraga berfungsi sebagai area bermain, berolahraga, pendidikan jasmani, upacara, dan kegiatan ekstrakurikuler. luas tempat bermain/berolahraga adalah $312 \mathrm{~m}^{2}$ kurang/tidak memenuhi kriteria, dan rasio minimium luas lapangan/ berolahraga adalah $1 \mathrm{~m}^{2} /$ siswa sehingga tidak memenuhi ketentuan untuk rasio minimum luas lahan. Di dalam luasan tersebut terdapat tempat berolahraga berukuran minimum $20 \mathrm{~m} \times 15 \mathrm{~m}$ yang memiliki permukaan datar, drainase baik, dan tidak terdapat pohon, saluran air, serta benda-benda lain yang mengganggu kegiatan berolahraga. sebagian dari tempat bermain ditanami pohon penghijauan disekitar lapangan atau di tepi lapangan, diletakkan di tempat yang paling sedikit mengganggu proses pembelajaran di kelas, tidak digunakan untuk tempat parkir. Sedangkan SDN 013 dan 021 Tempat bermain/berolahraga di sekolah memenuhi persyaratan yaitu: tempat bermain/berolahraga berfungsi sebagai area bermain, berolahraga, pendidikan jasmani, upacara, dan kegiatan ekstrakurikuler. rasio minimum luas tempat bermain/berolahraga adalah $3 \mathrm{~m}^{2} /$ siswa. jika banyak siswa kurang dari 180 orang, maka luas minimum tempat bermain/berolahraga adalah $540 \mathrm{~m}^{2}$, tetapi luas lapangan disdn 013 tarakan adalah 504 $\mathrm{m}^{2}$ dan rasio minimium luas lapangan/ berolahraga adalah $1 \mathrm{~m}^{2} /$ siswa sehingga tidak memenuhi ketentuan untuk rasio 
minimum luas lahan. Di dalam luasan tersebut terdapat tempat berolahraga berukuran minimum $20 \mathrm{~m} \times 15 \mathrm{~m}$ yang memiliki permukaan datar, drainase baik, dan tidak terdapat pohon, saluran air, serta benda-benda lain yang mengganggu kegiatan berolahraga. sebagian dari tempat bermain ditanami pohon penghijauan disekitar lapangan atau di tepi lapangan, diletakkan di tempat yang paling sedikit mengganggu proses pembelajaran di kelas, tidak digunakan untuk tempat parkir.

SDN 028 Tarakan mengadakan buku-buku kegiatan manajemen sarana dan prasarana yang terdiri atas: Buku Ekspedisi, Buku Administrasi Perpustakaan, buku statistik, papan Struktur Organisasi Sekolah, Buku Agenda Rapat, Buku Notulen Rapat, Buku Inventaris Sarana dan Prasarana, Buku Laporan Prasarana Sekolah, Buku Laporan Sarana Sekolah/Barang Inventaris Sekolah, Buku Pemeriksaan Sarana dan Prasarana. Sedangkan SDN 013 Tarakan Sekolah mengadakan buku-buku kegiatan manajemen sarana dan prasarana yang terdiri atas: Buku Ekspedisi, Buku Administrasi Perpustakaan, Struktur Organisasi Sekolah, Deskripsi Tugas Pendidik dan Tenaga Kependidikan, Buku Agenda Rapat, Buku Notulen Rapat, Buku Inventaris Sarana dan Prasarana, Buku Laporan Prasarana Sekolah, Buku Laporan Sarana Sekolah/Barang Inventaris Sekolah, Buku Pemeriksaan Sarana dan Prasarana. Begitupun SDN 021 mengadakan bukubuku kegiatan manajemen sarana dan prasarana yang terdiri atas 13 buku yaitu Daftar Usul Pengadaan Barang, Buku Pengumuman, Buku Administrasi Perpustakaan, Struktur Organisasi Sekolah, Deskripsi Tugas Pendidik dan Tenaga Kependidikan, Buku Statistik Sekolah, Buku Agenda Rapat, Buku Notulen Rapat, Buku Inventaris Sarana dan Prasarana, Buku Laporan Prasarana Sekolah, Buku Laporan Sarana Sekolah/Barang Inventaris Sekolah, Buku Pemeriksaan Sarana dan Prasarana, namun yang belum ada yaitu buku administrasi laboratorium, buku statistik sekolah, dan buku laporan penghapusan prasarana dan sarana sekolah.

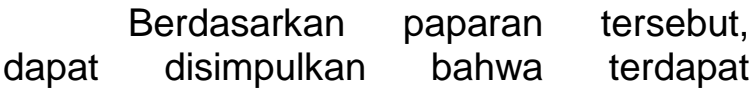

perbedaan yang sangat signifikan yaitu terletak pada tersedianya sarana dan prasarana di masing-masing sekolah. Kesesuain sarana prasarana sekolah dasar mengacu permen no 24 Tahun 2007 sebesar 80,9\% untuk SD 028 Tarakan (Akreditasi A), 78,7\% untuk SDN 013 Tarakan (Akreditasi B) dan 55,3\% untuk SDN 021 Tarakan (Akreditasi C). Pengelolaan sarana prasarana diteliti oleh Rosivia (2014) di SMPN 10 Padang. Sarana prasarana yang baik di sekolah dapat membuat kinerja guru mejadi lebih baik. Seperti yang diungkapkan Gagarin (2010) yang menyimpulkan bahwa terdapat pengaruh positif dan signifikan Sarana dan Prasarana Sekolah terhadap Kinerja Guru di Kabupaten Alor, NTT yang artinya semakin baik Sarana dan Prasarana Sekolah maka akan menghasilkan Kinerja Guru yang tinggi. Selain berimbas pada kinerja guru, sarana prasarana yang baik juga dapat membuat motivasi meningkat, hal ini senada dengan. Hal senada juga diungkapkan Fajriana (2014) yang menyatakan bahwa sarana prasarana sekolah memiliki efek yang signifikan terhadap prestasi belajar.

\section{SIMPULAN DAN SARAN}

Berdasarkan hasil observasi yang dilakukan pada tiga SD yaitu, SDN 028 Tarakan Terakreditasi A, SDN 013 Tarakan Terakreditasi B serta SDN 021 Tarakan Terakreditasi $\mathrm{C}$ dapat disimpulkan bahwa terdapat perbedaan yang sangat signifikan yaitu terletak pada tersedianya sarana dan prasarana di masing-masing sekolah. Kesesuain sarana prasarana sekolah dasar mengacu permen no 24 Tahun 2007 sebesar 80,9\% untuk SD 028 Tarakan (Akreditasi A), 78,7\% untuk SDN 013 Tarakan (Akreditasi B) dan 55,3\% untuk SDN 021 Tarakan (Akreditasi C).

\section{DAFTAR PUSTAKA}

Amirin, Tatang M. 2011. "Pengertian sarana dan prasarana pendidikan." tatangmanguny.wordpress.com

Anisawati, D. (2011, December 9). Hubungan Kondisi Dan Penggunaan Sarana Dan Prasarana Pendidikan Dengan Keefektifan Pembelajaran Di Smk Negeri Se-Kabupaten 
Tulungagung. Skripsi Jurusan Administrasi Pendidikan - Fakultas IImu Pendidikan UM. Retrieved from http://karya-

ilmiah.um.ac.id/index.php/ASP/article/ view/15168

Bianti, H, dkk. 2012. Pengaruh sarana prasarana dan cara belajar siswa Terhadap prestasi belajar siswa.ejournal.unesa.ac.id/article/839 1/99/article.pdf (diakses pada 15 November 2016)

Bsnp-Indonesia, tanpa tahun.Standar sarana dan prasarana.www.bsnpindonesia.org. Diakses tanggal 19 September 2016.

Darmawan, B. (2014). Manajemen Sarana dan Prasarana Dalam Meningkatkan Kualitas Pendidikan. Jurnal Pelopor Pendidikan, 6(2), 93-102. Retrieved from

http://www.stkippgrismp.ac.id/jurnalpelopor-pendidikan-4/

Fajriana, D.E. 2014. Pengaruh kualitas input, kompetensi guru, Sarana prasarana sekolah dan motivasi belajar Terhadap prestasi belajar siswa sman Pada mata pelajaran ekonomi tahun ajaran 2009/ 2010 di situbondo. Jurnal pedagogy vol. 01 no. 01 tahun 2014. ISSN 2354-6948

Gunawan, Ary H. 1996. Administrasi Sekolah "Administrasi Pendidikan Mikro" Jakarta : Rineka Cipta

Handayani, N. 2016. Dampak penerapan manajemen sarana Prasarana di daerah pesisir SDN 016 Tarakan. Skripsi. Tidak Dipublikasikan.

Ibrahim, B. (2004). Manajemen perlengkapan sekolah: Teori dan aplikasinya. Jakarta: Bumi Aksara.

Lunenburg, F.C. (2010). School facilities management. National Forum Of Educational Administration \& Supervision Journal. 27, 1-7.

Megasari, R. (2014). Peningkatan Pengelolaan Sarana Dan Prasarana Pendidikan Untuk Meningkatan Kualitas Pembelajaran di SMPN 5 Bukittinggi. Administrasi Pendidikan, 2, 1-13.
Mulyasa, E. (2004). Manajemen berbasis sekolah: Konsep, strategi, dan implementasi. Bandung: Remaja Rosdakarya.

Musa, M.F.,\& Zarita, A. (2012). Higher education physical assets and facilities. Journal of Procedia - Social and Behavioral Sciences, 50, 472 478.

Nelasari. 2012 Pengaruh Sarana Prasarana Pendidikan dan Motivasi Belajar Terhadap Hasil Belajar Mahasiswa. Jurnal Ilmu Kebidanan Indonesia.

Peraturan Menteri Pendidikan Nasional Republik Indonesia No. 4 Tahun 2007 tentang Standar Sarana dan Prasarana untuk Sekolah Dasar/Madrasah Ibtidaiyah (SD/MI), Sekolah Menengah Pertama/Madrasah Tsanawiyah (SMP/MTs), dan Sekolah Menengah Atas/Madrasah Aliyah (SMA/MA).

Peraturan Pemerintah Republik Indonesia No. 19 Tahun 2005 tentang Standar Nasional Pendidikan

Rosivia. 2014. Peningkatan pengelolaan sarana prasarana pendidikan di smp negeri 10 padang. Jurnal administrasi pendidikan Volume 2 Nomor 1, Juni 2014 Halaman 661 - 831

Sanjaya, W. (2008). Strategi pembelajaran berorientasi standar proses pendidikan. Jakarta: Kencana Prenada Media.

Santosa, Joko. 2011. Hubungan Manajemen Sarana dan Prasarana Sekolah, Dampak Sertifikasi Guru,Iklim Sekolah, Dan Motivasi Berprestasi Guru dengan Kinerja Guru pada SMK Negeri di Malang Raya. Disertasi.

Susanto, R., \& Sudira, P. (2016). Evaluasi Sarana Dan Prasarana Praktik Teknik Komputer Dan Jaringan Di Smk Kabupaten Sukoharjo. Jurnal Pendidikan Vokasi, 6(1), 54-65. Https://Doi.Org/10.21831/Jpv.V6i1.81 15

Timilehin, E.H. (2012). School facilities as correlates of students' achievement in the affective and psychomotor domains of learning. European Scientific Journal, 8, 208-215. 